\author{
Iwona Żuraszek-Ryś \\ Instytut Filologii Polskiej Uniwersytetu Zielonogórskiego
}

\title{
Dekomunizacja zielonogórskich urbanonimów
}

Obecnie jesteśmy świadkami zmian w nazewnictwie miejskim, spowodowanych wprowadzeniem tzw. ustawy dekomunizacyjnej. W niniejszym artykule zostanie opisana kwestia dekomunizacji ${ }^{1}$ urbanonimó $^{2} \mathrm{w}$ jednym $\mathrm{z}$ miast wojewódzkich, a mianowicie w Zielonej Górze. Celem analizy będzie wskazanie tendencji w przemianowaniach nazw spowodowanych określoną zmianą polityczno-historyczną, tj. transformacją ustrojową po 1989 roku, oraz uchwaleniem w 2016 roku tzw. ustawy dekomunizacyjnej. Wprawdzie rozważania ograniczono tylko do konkretnej miejscowości, mogą one jednak stanowić uzupełnienie dotychczasowych badań i opisu omawianego zagadnienia w aspekcie ogólnopolskim, zwłaszcza w odniesieniu do przemianowań związanych $\mathrm{z}$ ostatnią dekomunizacją.

Z pierwszym usuwaniem komunistycznych patronów w dziejach miasta mieliśmy do czynienia jeszcze w czasach komunistycznych, po śmierci Stalina w 1953 roku. W 1954 roku pl. marszałka Roli-Żymierskiego przemianowano na $\mathrm{pl}$. Kolejarza (notabene nazwę wprowadzono w latach 40. XX wieku w celu upamiętnienia tej postaci i jej pobytu w mieście, nazwano tak plac przed dworcem kolejowym). Nazwisko tego marszałka usunięto z tabliczek po tym, jak

1 Dekomunizacja - usuwanie elementów i struktur charakterystycznych dla systemu komunistycznego lub osób związanych z tym systemem, https://wsjp.pl/index.php?id_hasla=48071\&ind=0\&w_szukaj=dekomunizacja+\# [dostęp: 5 marca 2019].

2 Urbanonim - nazwa własna obiektu występującego w przestrzeni miejskiej, np. ulicy, placu, parku, budynku, instytucji, https://onomastyka.uni.lodz.pl/strona-glowna/terminologia-polska [dostęp: 5 marca 2019]. Przedmiotem omówienia będą w niniejszym artykule nazwy ulic, alei i miejskich placów. 
został zamknięty w więzieniu przez swoich towarzyszy. Nie mógł być więc dalej patronem ulicy.

27 października 1956 roku podczas sesji Rady Miasta zmieniono z kolei nazwę ul. Stalina na al. Niepodległości. Według przedstawicieli lokalnych władz było to zachowanie podyktowane zapotrzebowaniem społecznym i żądaniem mieszkańców. Jak odnotowano w protokole:

[...] w oparciu o inicjatywę szerokich mas społeczeństwa zielonogórskiego odczytał [radny Blum - I.Ż.R.] propozycje zgłoszone przez mieszkańców przemianowania ul. Stalina. Na apel „Gazety Zielonogórskiej” wpłynęło od pracowników z szeregu zakładów i instytucji wiele projektów nowych nazw tej ulicy. [Czyżniewski 2014: 8]

Ta argumentacja nie wydaje się jednak przekonująca, gdyż prośba o listowne lub telefoniczne wypowiedzenie się w sprawie przemianowania ul. Stalina ukazała się w gazecie na dwa dni przed sesją. W ciągu tak krótkiego czasu nie było raczej możliwe zareagowanie na ten komunikat przez wielu zielonogórzan. Nazwę zmieniono, ponieważ po dojściu do rządów Władysława Gomułki, w okresie tzw. odwilży, osłabienia wpływu władzy partyjnej i państwowej na życie społeczne, ten komunistyczny patron (podobnie jak wcześniej Rola-Żymierski) przestał już odpowiadać władzy. Co jednak ciekawe, wraz ze zmianą tej nazwy dla niepoznaki przemianowano również inne ulice, np. zamiast nazwy ul. Widok wprowadzono nazwę ul. Chopina.

Dokonane wtedy przemianowania nazw ulic i placów objęły nie tylko Zieloną Górę, ale też wiele innych polskich miast, np. w Warszawie w latach 1949-1957 funkcjonowała nazwa ul. Józefa Stalina (dawniej ul. Józefa Pitsudskiego), którą następnie zmieniono na ul. Bohaterów Warszawy. Z kolei w Bydgoszczy w latach 1950-1956 była nazwa ul. Generalissimusa Stalina, którą zastąpiono nazwą poprzednią - ul. Jagiellońska. Przeprowadzone wówczas zmiany miały jednak inny charakter niż późniejsze. Doszło bowiem wtedy tylko do czasowego odejścia od sztywnych zasad polityki nazewniczej motywowanej względami ideologicznymi, a nie do zerwania z systemem komunistycznym i jego symbolami.

Z właściwą dekomunizacją mieliśmy do czynienia po raz pierwszy po upadku komunizmu w 1989 roku. Wraz ze zmianą systemu politycznego, pociągającego za sobą zmianę ustroju państwa z komunistycznego na demokratyczny, pojawiła się, podobnie zresztą jak w innych miastach Polski, potrzeba usunięcia nazw odzwierciedlających wartości preferowane przez władze PRL-u. Dla wielu ludzi była to niezwykle istotna i pilna kwestia. 
Wiesław Myszkiewicz - badacz zielonogórskiego nazewnictwa miejskiego - tak opisuje te wydarzenia:

Przełom ustrojowy 1989 r. spowodował zainteresowanie kwestią nazewnictwa. Najpierw podnieśli ją działacze Komitetów Obywatelskich. Dla części z nich sprawa wymiany tablic nazewniczych zdawała się być najpilniejszym problemem w procesie przemian ustrojowych. $\mathrm{W}$ dyskusjach na ten temat było równie wiele elementów racjonalnych, co i demagogii; stosunek do zmian nazewniczych okrzyknięto niemal jako miarę i kryterium patriotyzmu. Wybory do nowej Rady Miejskiej i zdominowanie jej przez radnych Komitetu Obywatelskiego stworzyły odpowiednie warunki polityczne dla wprowadzenia zmian w nazewnictwie. [Myszkiewicz 1997: 448]

W ten sposób na kolejnych sesjach Rady Miejskiej w 1990 roku przedmiotem obrad uczyniono zmianę niepożądanych urbanonimów, związanych z poprzednim ustrojem. Dyskusje były dość burzliwe. Na przykład pewne kontrowersje budziła nazwa ul. Anieli Krzywoń. Zdaniem niektórych radnych patronka tej ulicy nie pasowała ze względu na swoje przekonania do propagowanego w nowej wolnej Polsce modelu patriotyzmu. Zważywszy na skojarzenia ze znienawidzonym reżimem, należało ich zdaniem zlikwidować ten obcy światopoglądowo symbol. Jak pisał Myszkiewicz: „Trzeba było zdecydować, czy stała się ona bohaterką niewłaściwego wojska i niesłusznej bitwy, czy nieszczęsną ofiarą tragedii dziejowej. Przyjęto tę drugą wersję i nazwa ulicy nie została zmieniona" [Myszkiewicz 1997: 448-449]. Tego typu dyskusje pokazują, jak urbanonimy stają się przedmiotem działań polityczno-ideologicznych, służących kształtowaniu świadomości historycznej społeczeństwa. Władza lokalna, wskazując na preferowane przez siebie wzorce i system wartości, kreuje tym samym odpowiadający jej obraz rzeczywistości.

Zaopiniowane pozytywnie przez radnych propozycje nowych urbanonimów zostały zatwierdzone i uzyskały postać uchwał. W uchwale z 20 lutego 1990 roku (nr X/66/90) znajdziemy zapis o zmianie nazwy dwóch pierwszych ulic - ul. B. Bieruta na ul. Zachodnia oraz ul. F. Dzierżyńskiego na ul. Władystawa IV, natomiast w uchwale z 21 sierpnia 1990 roku (nr IV/32/90) - nazwy ul. Matgorzaty Fornalskiej na ul. Bankowa. Z kolei w uchwale Rady Miejskiej z 23 października 1990 roku (nr V/65/90) zamieszczono 22 nowe nazwy. Zostały one przedstawione w tabeli 1 . 
Tabela 1. Wykaz nazw zamieszczonych w uchwale Rady Miasta Zielona Góra z 23 października 1990 roku (nr V/65/90)

\begin{tabular}{|c|c|}
\hline Dotychczasowa nazwa & Nowa nazwa \\
\hline pl. Bohaterów Stalingradu & Stary Rynek \\
\hline Buczka & Klementowskich \\
\hline Findera & Armii Krajowej \\
\hline Gwardii Ludowej & Prymasa Wyszyńskiego \\
\hline Jedności Robotniczej & Jedności \\
\hline gen. F. Jóźwiaka & Monte Cassino \\
\hline płk. Kowalskiego & Wileńska \\
\hline Krajowej Rady Narodowej & Podgórna \\
\hline $\begin{array}{l}\text { Podgórna } \\
\text { (na odcinku od pl. Matejki do Bankowej) }\end{array}$ & Kocia* \\
\hline J. Krasickiego & Ignacego Krasickiego \\
\hline pl. Lenina & pl. Pocztowy \\
\hline K. Marksa & Pod Filarami \\
\hline M. Nowotki & Lwowska \\
\hline Jakuba Szeli & Truskawkowa \\
\hline gen. Świerczewskiego & Kupiecka \\
\hline Walki Młodych & Dworcowa \\
\hline Hanki Sawickiej & gen. Okulickiego \\
\hline A. Warskiego & dr Pieniężnego \\
\hline gen. Waszkiewicza & Marszałka Rydza-Śmigłego \\
\hline A. Zawadzkiego & Tadeusza Zawadzkiego „Zośki” \\
\hline F. Zubrzyckiego & Świętych Cyryla i Metodego \\
\hline os. XXXV-lecia PRL & os. Piastowskie \\
\hline
\end{tabular}

* W tym wypadku doszło przy okazji przemianowań do wydzielenia nowej ulicy. Z tego też względu jej nazwa nie będzie przedmiotem rozważań w dalszej części pracy. 
Uchwałą z 21 grudnia 1990 roku (nr VIII/92/90) wprowadzono natomiast poprawki do podjętej wcześniej uchwały, ustanawiając zamiast: ul. Prymasa Wyszyńskiego $\rightarrow$ ul. Stefana Wyszyńskiego, ul. gen. Okulickiego $\rightarrow$ ul. Leopolda Okulickiego, ul. Marszałka Rydza-Śmigłego $\rightarrow$ ul. Rydza-Śmigłego.

Wraz z upadkiem komunizmu w 1989 roku doszło do zmian w ukształtowanej po II wojnie światowej szacie ideologicznej miasta ${ }^{3}$. Przemianowane zostały przede wszystkim onimy określane tradycyjnie jako pamiątkowe czy symboliczne. Andrzej Chludziński zaproponował, aby mówić raczej o motywacjach ideologicznych: „Przede wszystkim zmieniono nazwy zaliczane do kategorii pamiątkowych, niekiedy też zwanych symbolicznymi, choć - nazywając rzeczy po imieniu lepiej by było mówić o motywacjach ideologicznych" [Chludziński 2004b: 358]. Wśród zielonogórskich nazw pamiątkowych odwołujących się do minionego systemu najliczniejszą grupę stanowiły urbanonimy oparte na antroponimach. Jedną z tendencji było zastąpienie ich takim samym typem. W wyniku transformacji ustrojowej możliwe stało się bowiem zerwanie $\mathrm{z}$ dotychczasową tradycją poprzez usunięcie niepopularnych nazw, motywowanych nazwiskami osób kojarzących się ze znienawidzonym reżimem, a także wykreowanie nowych symboli - osób, które dotychczas nie mogły być upamiętnione, miały być wymazane z pamięci potomnych, np.: Leopolda Okulickiego - uczestnika I i II wojny światowej, a przede wszystkim ostatniego dowódcy Armii Krajowej, czy Edwarda Rydza-Śmigłego - działacza niepodległościowego, marszałka Polski, generalnego inspektora Sił Zbrojnych, Naczelnego Wodza Polskich Sił Zbrojnych w wojnie obronnej 1939 roku. Warto jednak zauważyć, że zastąpienie w nazwach ulic i placów nieakceptowanych patronów przez osoby, które dotychczas nie mogły być upamiętnione, nie było wcale dominującą tendencją. Wprowadzono wtedy tylko trzy tego typu urbanonimy: ul. Leopolda Okulickiego, ul. Rydza-Śmigłego i ul. Tadeusza Zawadzkiego „Zośki”. W wypadku tej ostatniej nazwy wykorzystano zbieżność nazwisk patronów, zastępując nazwę ul. A. Zawadzkiego - nazwą ul. Tadeusza Zawadzkiego „Zośki”. Podobnie zresztą uczyniono w wypadku urbanonimu ul. J. Krasickiego, który zastąpiono ul. Ignacego Krasickiego.

Patronami nowych ulic stali się ponadto nieobecni w nazewnictwie miejskim minionego systemu duchowni i święci: Stefan Wyszyński (ul. Stefana Wyszyńskiego) oraz Cyryl i Metody (ul. Świętych Cyryla i Metodego).

3 Według Floriana Zielińskiego pojęcie szaty ideologicznej miasta odnosi się do nazw ulic i placów, patronów zakładów pracy, szkół i uczelni, nazw klubów sportowych i nazw produktów, wyposażenia miasta w pomniki i w zmienną szatę plakatów i afiszy [Zieliński 1994: 190]. 
Wśród nowych nazw opartych na antroponimach znalazły się również urbanonimy upamiętniające lokalne postaci: doktora Zbigniewa Pieniężnego - znanego w mieście chirurga, związanego z Zieloną Górą od 1946 roku (ul. dr Pieniężnego) oraz Klementowskich - starostę Jana Klementowskiego i jego żonę Stefanię, znaną nauczycielkę (ul. Klementowskich).

Wprowadzono także nazwy mające dawne, utrwalone w systemie miejskim historyczne uzasadnienie, nawiązujące nawet do niemieckiej przeszłości miasta: ul. Bankowa (dawna Hindenburgstrasse, po wojnie przemianowana na ul. Bankowa, a następnie na ul. Małgorzaty Fornalskiej; przy ulicy jest zlokalizowana siedziba banku), Stary Rynek (dawny Ring, po wojnie przemianowany na Stary Rynek, a następnie na pl. Bohaterów Stalingradu), pl. Pocztowy (dawny Postplatz, po wojnie przemianowany na $p l$. Zgody, a następnie na $p l$. Lenina). $\mathrm{Z}$ tego typu przemianowaniami mieliśmy do czynienia także w innych miastach, które przed II wojną światową znajdowały się poza granicami Polski ${ }^{4}$.

Ponadto zamiast dotychczasowych mian pojawiły się urbanonimy o charakterze topograficznym, odwołujące się do naturalnej i stworzonej przez ludzi przestrzeni organizmu miejskiego: $u l$. Dworcowa (dawna Hatzfeldstrasse, po wojnie przemianowana na $u l$. Walki Młodych; znajduje się przy dworcu PKS i PKP), ul. Kupiecka (dawna Niederstrasse, po wojnie przemianowana na ul. Pionierska, a następnie na ul. Karola Świerczewskiego; przez wiele lat była to główna ulica handlowa w mieście), ul. Podgórna (dawna Altkesslerstrasse, po wojnie przemianowana na ul. Podgórna, a następnie na ul. Krajowej Rady Narodowej; nazwa nadana ze względu na jej położenie), ul. Pod Filarami (dawna Poststraße, po wojnie przemianowana na $u l$. Pocztowa, a następnie na ul. Karola Marksa; taka nazwa funkcjonowała wśród zielonogórzan, a pochodzi ona od charakterystycznego budynku znajdującego się na tej ulicy), ul. Zachodnia (wcześniej ul. Bolesława Bieruta; znajduje się w zachodniej części miasta). Najwięcej przemianowanych nazw reprezentuje właśnie ten typ. Są one szczególnie pożądane, gdyż ułatwiają orientację przestrzenną w mieście.

Jak pisała Danuta Kopertowska:

Jeśli już decydujemy się na przeprowadzenie zmian w nazewnictwie, warto zadbać, aby służyły one wyższemu, niż tylko fasadowa wymiana ideologii, celowi. A nadrzędnym celem w zakresie nazewnictwa powinno być to, aby

4 Andrzej Chludziński pisał np. o przywracaniu tego typu nazw w Białogardzie [Chludziński 2004a: 403]. 
było ono swojskie, na miejscowych realiach topograficznych i kulturowych, na własnej przeszłości i teraźniejszości oparte. [Kopertowska 1998: 154]

Nazwy odwołujące się do historii i topografii miasta, a także do lokalnych działaczy i bohaterów są wskazane, gdyż nadają miastu indywidualny styl i charakter. Są świadectwem jego dziejów i rozwoju. Wprowadzanie tego typu nazw wiąże się zatem z kształtowaniem społecznej i kulturowej tożsamości mieszkańców miasta, ich poczucia przynależności do danej społeczności, mającej określoną przeszłość czy zamieszkującej konkretne terytorium.

Wśród nowych nazw znalazły się również formy upamiętniające Armię Krajową - konspiracyjną organizację wojskową (ul. Armii Krajowej), bitwę pod Monte Cassino (ul. Monte Cassino), a także miasta szczególnie bliskie przesiedleńcom z dawnych Kresów Wschodnich, miejscowości, z których pochodzili - Wilno (ul. Wileńska) i Lwów (ul. Lwowska).

Jedną ze starych nazw poddano modyfikacji, polegającej na jej skróceniuul. Jedności Robotniczej została przemianowana na ul. Jedności (notabene nazwa ta przez wiele lat funkcjonowała w takiej postaci wśród zielonogórzan).

Wprowadzone wtedy zmiany miały zbliżony charakter do zmian w innych polskich miastach ${ }^{5}$. Objęły podobne typy nazw, np. motywowanych patronami kojarzonymi z komunizmem (dowódcami, bohaterami z czasów II wojny światowej, działaczami komunistycznymi czy ideologami ruchu komunistycznego), określeniami polskich organizacji wojskowych z czasów II wojny światowej. Przy tym należy zauważyć, że tylko w przypadku części zielonogórskich nazw (głównie o charakterze topograficznym) powrócono do nazw sprzed komunizacji. Wiele nazw ulic o wyraźnym rysie ideologicznym, kojarzonych z komunizmem nadano w Zielonej Górze dopiero w latach 60. i 70. w związku z budową nowych osiedli mieszkaniowych. Nie miały one zatem innego wcześniejszego miana. Nie było więc możliwości zastąpienia ich starymi, utrwalonymi w systemie miejskim nazwami, jak to miało miejsce w innych polskich miastach ${ }^{6}$. Natomiast jeśli chodzi o urbanonimy motywowane antroponimami, to zastąpienie w nazwach ulic i placów nieakceptowanych patronów przez osoby, które dotychczas nie mogły być upamiętnione, nie było wcale dominującą, jak już

5 Badania dotyczące dekomunizacji były i są prowadzone w różnych polskich miastach, a ich efektem są liczne publikacje [zob. np. Bieńkowska, Umińska-Tytoń 2012; Chludziński 2004a, 2004b; Handke 1997; Jaracz 1988; Kopertowska 1998].

6 Na przykład w Bydgoszczy, jak pisała Małgorzata Jaracz, dużą grupę stanowiły nazwy sprzed 1939 roku, zmienione po wojnie ze względów koniunkturalnych, a których przywrócenie spotkało się z aprobatą bydgoszczan [Jaracz 1988: 41]. 
wcześniej wspominałam, tendencją. Wynikało to z założeń przyjętych przez radnych. Jak wspominał Edward Mincer:

Później wypracowaliśmy koncepcję, jestem jednym z jej autorów, by patronów politycznych zamienić na naturalnych, ułatwiających identyfikację miejsca na mapie. Stąd pl. Pocztowy, ul. Pod Filarami lub Dworcowa. Bohaterów Stalingradu zamieniliśmy na Stary Rynek, chociaż pojawiły się również propozycje, by był to plac Piłsudskiego. [Czyżniewski 2017: 8]

Obecnie jesteśmy świadkami zmian w nazewnictwie miejskim, spowodowanych wprowadzeniem tzw. ustawy dekomunizacyjnej (Ustawa z dnia 1 kwietnia 2016 r. o zakazie propagowania komunizmu lub innego ustroju totalitarnego przez nazwy budowli, obiektów i urządzeń użyteczności publicznej). $\mathrm{W}$ artykule pierwszym tego dokumentu możemy przeczytać:

1. Nazwy budowli, obiektów i urządzeń użyteczności publicznej, w tym dróg, ulic, mostów i placów, nadawane przez jednostki samorządu terytorialnego nie mogą upamiętniać osób, organizacji, wydarzeń lub dat symbolizujących komunizm lub inny ustrój totalitarny, ani w inny sposób takiego ustroju propagować. 2. Za propagujące komunizm uważa się także nazwy odwołujące się do osób, organizacji, wydarzeń lub dat symbolizujących represyjny, autorytarny i niesuwerenny system władzy w Polsce w latach 1944-1989. [Dz.U. 2016, poz. 744]

Zgodnie z przedstawionymi zasadami każda uprawniona do nadawania nazw jednostka samorządu terytorialnego powinna w ciągu roku od wejścia w życie ustawy (czyli do 2 września 2017 roku) zmienić miana propagujące system totalitarny. Nie wszystkie samorządy zdołały jednak dokonać przemianowań w określonym czasie. W tym wypadku - zgodnie z przepisami - zajęli się tą kwestią wojewodowie. $Z$ taką sytuacją mieliśmy do czynienia w Zielonej Górze. Co prawda, we wrześniu 2016 roku Rada Miasta Zielona Góra powołała doraźną komisję do spraw nazewnictwa, która miała działać do końca roku i zająć się m.in. wdrażaniem w życie ustawy dekomunizacyjnej, ale jej członkowie nie mogli dojść do porozumienia w sprawie nowych urbanonimów i nie przedstawili Radzie Miasta Zielona Góra propozycji zmian. Ostatecznie obowiązek nadania nazw przypadł zatem wojewodzie.

W 2017 roku w Zielonej Górze pozostały do zmiany tylko cztery nazwy ulic: II Armii, Armii Ludowej, Przylep-22 Lipca oraz Przylep-9 Maja ${ }^{7}$. Wiele

7 Dwie ostatnie nazwy znajdują się w tzw. Nowym Mieście. 1 stycznia 2015 roku do miasta włączono gminę Zielona Góra (obejmującą 17 wsi, w tym Przylep). W ten sposób powstała 
urbanonimów upamiętniających komunizm zmieniono bowiem wcześniej. Mimo że do przemianowania było tak mało urbanonimów, to i tak dyskusja nad zmianami budziła wiele emocji. Najmniej kontrowersji było z dwoma ulicami: ul. Armii Ludowej oraz ul. Przylep-9 Maja. Dla tej pierwszej radni zaproponowali nazwę ul. Władystawa Jagiełty. Wojewoda lubuski przychylił się do tej propozycji i w zarządzeniu wskazał takie miano. Podobnie uczynił w stosunku do nazwy ul. Przylep-9 Maja, którą zastąpiono mianem ul. Przylep-8 Maja. W tym wypadku doszło do wprowadzenia innej daty $-\mathrm{z}$ terminu zakończenia II wojny światowej, uznawanego przez Rosjan, a wcześniej przez Związek Radziecki i kraje przez niego zniewolone, na datę ogólnie przyjętą przez państwa zachodnie.

Inaczej wojewoda postąpił w przypadku dwóch pozostałych urbanonimów. Nie przyjął propozycji radnych i zaproponował nowe miana. Jeśli chodzi o nazwę ul. Przylep-22 Lipca, to radni stwierdzili, że mogłaby ona pozostać, ale należałoby znaleźć dla niej nowe uzasadnienie: nie dzień propagandowej - choć nieprawdziwej - daty powstania Polskiego Komitetu Wyzwolenia Narodowego (PKWN), ale rocznicę zwycięskiej bitwy Bolesława Chrobrego z księciem kijowskim Jarosławem Mądrym w 1018 roku. Na początku i końcu ulicy miały zostać ustawione tablice z informacją, o który 22 lipca chodzi. Miał to być sposób na dekomunizację bez ponoszenia kosztów zmian adresów. Władza chciała oszczędzić mieszkańcom tej ulicy wydatków związanych z kolejną w ciągu dwóch lat zmianą urbanonimu (przypomnijmy, że 1 stycznia 2015 roku do miasta włączono gminę Zielona Góra i powstała nowa jednostka samorządu terytorialnego). Uwzględnienie okoliczności ekonomicznych podczas przemianowań powinno być niezwykle istotne, gdyż zmiany nazw ulic, alei czy placów są z reguły drogie i wymagają np. od mieszkańców poniesienia kosztów związanych z wymianą niektórych dokumentów, tablic, reklam. Wojewoda nie zgodził się jednak na zmianę kontekstu historycznego i zaproponował ul. Solidarności. Po raz kolejny względy ideologiczne okazały się ważniejsze.

Jeśli chodzi natomiast o ostatnią ulicę, to radni mieli dość rozbieżne zdania co do konieczności jej przemianowania. Na przykład Andrzej Brachmański z klubu Zielona Razem wypowiadał się w następujący sposób: „To skandal! Miliony chłopaków zostały wcielone do armii, bo nie mieli wyboru. Przelewali krew, walcząc z Niemcami. A teraz mamy powiedzieć swoim dziadkom, że umierali na darmo?!" [Kalinowski 2017: 5]. Podczas debaty zwrócono jeszcze uwagę, że II Armia całkiem niedawno pojawiła się w nazwie nowego ronda -

nowa jednostka administracyjna, złożona $\mathrm{z}$ dwu odrębnych do tej pory jednostek samorządu terytorialnego. Na terenie dawnej gminy Zielona Góra utworzono dzielnicę Nowe Miasto, która od 2 stycznia 2015 roku funkcjonuje jako część administracyjna miasta Zielona Góra. 
Osadników Wojskowych i II Armii (2016), mimo że przy jej ustalaniu także było sporo emocji. Ostatecznie zaproponowano pozostawienie dotychczasowej nazwy. Wojewoda nie poparł jednak tej propozycji i zaproponował ul. Ofiar Komunizmu, argumentując, że nazwa ul. II Armii w mieście Zielona Góra jest niezgodna z art. 1 ustawy. Powoływał się przy tym na opinię Instytutu Pamięci Narodowej:

nazwę ulicy II Armii w Zielonej Górze należy identyfikować z II Armią Wojska Polskiego powołaną do życia przez władze Związku Sowieckiego - bez zgody władz Rzeczypospolitej Polskiej w 1944 r. [...] Na powyższe w ocenie IPN wskazuje fakt, iż do nadania wymienionej nazwy doszło poprzez uchwałę z dnia 29 czerwca 1973 r. nr XXV/98/73 funkcjonującej w okresie PRL-u Miejskiej Rady Narodowej, a nadto nazwa ta dotyczy ulicy położonej na terenie Osiedla Łużyckiego w Zielonej Górze. Z analizy praktyki propagandowej władz komunistycznych wynika, iż w tamtym okresie PRL w pierwszym rzędzie honorowano w nazwach ulic tego typu związki operacyjne tworzone przy Armii Czerwonej. Nie ma możliwości, aby w tamtych czasach przedmiotem uhonorowania była II Armia istniejąca w strukturach Wojska Polskiego w okresie wojny polsko-bolszewickiej 1919-1921. Nadto rozpatrywana nazwa dotyczy ulicy położonej na terenie Osiedla Łużyckiego, co wpisuje się w historię wykorzystania w ostatnim okresie wojny II Armii Wojska Polskiego stworzonej przy Armii Czerwonej. Brała ona bowiem udział m. in. w operacji forsowania Nysy Łużyckiej - tj. rzeki, której drugi człon nazwy (Łużycka) jest zbieżny z nazwą wymienionego osiedla. Tym samym w ocenie Instytutu Pamięci Narodowej - Komisji Ścigania Zbrodni przeciwko Narodowi Polskiemu - nazwa ulicy II Armii (Wojska Polskiego) dotyczy organizacji (wojskowej jednostki taktycznej) symbolizującej komunizm w rozumieniu art. 1 ust. 1 ustawy. [Dz.U. Województwa Lubuskiego, 2017, poz. 2703]

Propozycja wojewody nie spotkała się z akceptacją mieszkańców. Poprosili więc władze miasta o podjęcie działań zmierzających do zmiany decyzji wojewody, argumentując, że dopiero teraz ulica będzie się kojarzyła z komunizmem, w potocznym bowiem obiegu nazwa ta może być używana w postaci ul. Koтипizmu. Obecny w nazwie wyraz komunizm będzie więc ciągle przywoływał miniony okres. W konsekwencji skutek będzie zatem odwrotny do przesłanek ustawy dekomunizacyjnej. W zamian mieszkańcy zaproponowali nazwę $u l$. Żotnierzy 2 Armii. Wojewoda i IPN zaopiniowali propozycję mieszkańców pozytywnie, a na marcowej sesji (27 marca 2018) także radni przyznali rację mieszkańcom, przegłosowując uchwałę w tej kwestii. 
Co ciekawe, nazwa ta nie upamiętnia żołnierzy II Armii Wojska Polskiego walczących podczas II wojny światowej (a zgodnie z wytycznymi IPN nowa nazwa mogła być wyrazem ich uhonorowania), lecz wojaków biorących udział w wojnie polsko-bolszewickiej. W uzasadnieniu do uchwały możemy bowiem przeczytać:

2 Armia utworzona została w trakcie wojny polsko-bolszewickiej z rozkazu generała Józefa Piłsudskiego z 7 marca 1920 r. Brała ona udział w Bitwie Warszawskiej w 1920 r., podczas której pod dowództwem generała Bolesława Roi m.in. broniła przepraw na Wiśle. Ostatnim dowódcą 2 Armii był gen. Edward Śmigły-Rydz, którego imię nosi ulica równoległa do obecnej ul. Ofiar komunizmu. [Uchwała Rady Miasta Zielona Góra, 2018, nr LXV.934.2018]

Ostatnia dekomunizacja nazw miejskich po raz kolejny obnażyła intencje osób odpowiedzialnych za przemianowania. Unaoczniła, że urbanonimy są nie tylko świadectwem zmian społeczno-politycznych zachodzących w Polsce, ale i widocznym śladem politycznego nacisku i manipulacji. Są ważnym narzędziem w dyskursie publicznym, służącym kształtowaniu społecznej świadomości, a nawet manipulowaniu nią przez rządzących. Wybór określonych patronów świadczy bowiem o wartościach i wzorach preferowanych przez osoby uprawnione do nadawania nazw, odzwierciedla ich przekonania, poglądy polityczne i służy kreowaniu określonego, to jest odpowiadającego władzy, obrazu rzeczywistości.

Reasumując, w artykule przedstawiono motywacje przemianowań zielonogórskich urbanonimów spowodowanych dekomunizacją. Pierwsza z nich była związana z transformacją ustrojową po 1989 roku. Dotychczasowe urbanonimy oparte głównie na antroponimach zastąpiono wtedy m.in. nazwami odnoszącymi się do osób i wydarzeń, które wcześniej nie mogły być upamiętnione, miały być wymazane z pamięci potomnych, a także do osób związanych z miastem. Ponadto wprowadzono nazwy odwołujące się do historii oraz topografii miasta. Ostatnia dekomunizacja została wymuszona uchwaleniem ustawy zabraniającej propagowania komunizmu lub innych systemów totalitarnych. W jej wyniku zielonogórskie nazwy ulic odwołujące się do organizacji wojskowych kojarzonych z ruchem komunistycznym zmieniono na nazwy upamiętniające władcę Polski (ul. Armii Ludowej $\rightarrow$ ul. Władysława Jagiełty) oraz patronów grupowych (ul. II Armii $\rightarrow u l$. Żotnierzy 2 Armii). Z kolei urbanonimy oparte na datach zastąpiono nazwami, z których jedna upamiętnia ruch o charakterze społeczno-niepodległościowym, powstały przeciw rządom komunistycznym w PRL-u (ul. Przylep-22 Lipca $\rightarrow$ ul. Przylep-Solidarności), 
a w przypadku drugiej - wprowadzono inną datę odnoszącą się do zakończenia II wojny światowej, uznawaną powszechnie w państwach zachodnich (ul. Przylep-9 Maja $\rightarrow$ ul. Przylep-8 Maja).

Wszelkie zmiany polegające na usunięciu nazw kojarzących się z komunizmem traktowano jako zerwanie ze spuścizną minionego czasu, a wprowadzenie nowych nazw - jako odzwierciedlenie nowego porządku czy ustroju. W przypadku obu dekomunizacji nadrzędne okazywały się zatem względy ideologiczne, w mniejszym zaś stopniu kulturowe czy ekonomiczne.

\section{Bibliografia}

Bieńkowska Danuta, Umińska-Tytoń Elżbieta (2012), O niektórych mechanizmach zmian urbonimów (nazwy pośrednio motywowane w nazewnictwie tódzkim), „Studia Językoznawcze Uniwersytetu Szczecińskiego", t. 11, s. 37-46.

Chludziński Andrzej (2004a), Motywacje zmian nazw ulic w Polsce od 1989 roku (na przykładzie kilku miast pomorskich), ,Studia Językoznawcze. Synchroniczne i diachroniczne aspekty badań polszczyzny”, t. 3, s. 397-404.

Chludziński Andrzej (2004b), Transformacja ustrojowa w Polsce po 1989 roku z onomastyka w tle, w: Stowo. Tekst. Czas VII. Nowe środki nominacji językowej w nowej Europie. Materiaty VII Międzynarodowej Konferencji Naukowej, Szczecin, 21-23 listopada 2003 r., red. Michaił Aleksijenko, Marzanna Kuczyńska, Wydawnictwo US, Szczecin, s. 355-361.

Czyżniewski Tomasz (2014), Ulica Stalina i Hindenburga, „Łącznik Zielonogórski”, 12 grudnia 2014.

Czyżniewski Tomasz (2017), Lenin z Marksem do lamusa, „Łącznik Zielonogórski”, 10 lutego 2017.

Handke Kwiryna (1997), Przemiany w polskim nazewnictwie miejskim ostatniego pótwiecza jako obraz działań pragmatycznych, w: Rozważania i analizy językoznawcze, red. Kwiryna Handke, Slawistyczny Ośrodek Wydawniczy, Warszawa, s. 469-475.

Jaracz Małgorzata (1988), Współczesna praktyka nazewnicza w Bydgoszczy (na przykladzie prac Zespołu ds. Nazewnictwa Miejskiego w latach 1990-1994), w: Varia linguistica, red. Łucja Szewczyk, Wydawnictwo Uczelniane WSP w Bydgoszczy, Bydgoszcz, s. 39-48.

Kalinowski Leszek (2017), Nazwy ulic i pomnik ktuja w oczy, „Gazeta Lubuska”, 2 października 2017.

Kopertowska Danuta (1998), Kierunki zmian w powojennym nazewnictwie Kielc (1945-1995), w: Najnowsze przemiany nazewnicze, red. Ewa Jakus-Borkowa, Krystyna Nowik, Energeia, Warszawa, s. 147-155. 
Kownacki Edmund (1994), Społeczne i polityczne uwarunkowania nazewnictwa poznańskich ulic, w: Język a współczesne społeczeństwo polskie, red. Zygmunt Zagórski, Poznańskie Towarzystwo Przyjaciół Nauk, Poznań, s. 19-28.

Myszkiewicz Wiesław (1997), Ulice Zielonej Góry, w: Wokól niemieckiego dziedzictwa kulturowego na Ziemiach Zachodnich i Północnych, red. Zbigniew Mazur, Instytut Zachodni, Poznań, s. 433-469.

Uchwała Rady Miasta Zielona Góra (2018), nr LXV.934.2018.

Ustawa z dnia 1 kwietnia 2016 r. o zakazie propagowania komunizmu lub innego ustroju totalitarnego przez nazwy budowli, obiektów i urzadzeń użyteczności publicznej, Dz.U. 2016, poz. 744.

Wielki słownik języka polskiego, red. Piotr Żmigrodzki, https://wsjp.pl/index. php?pwh=0 [dostęp: 5 marca 2019].

Zarzadzenie zastęcze NK-I.4131.205.2017.AHOR wojewody lubuskiego, „Dziennik Urzędowy Województwa Lubuskiego" 2017, poz. 2700.

Zarządzenie zastępcze NR NK-I.4131.265.2017.AHOR wojewody lubuskiego, „Dziennik Urzędowy Województwa Lubuskiego" 2017, poz. 2701.

Zarzadzenie zastępcze NR NK-I.4131.266.2017.AHor wojewody lubuskiego, „Dziennik Urzędowy Województwa Lubuskiego" 2017, poz. 2702.

Zarządzenie zastepcze NR NK-I.4131.267.2017.AHOR wojewody lubuskiego, „Dziennik Urzędowy Województwa Lubuskiego" 2017, poz. 2703.

Zieliński Florian (1994), Szata ideologiczna miasta. O przemianowywaniu ulic i placów, w: Miasta polskie w dwusetlecie prawa o miastach, red. Ewa Kaltenberg-Kwiatkowska, Polskie Towarzystwo Socjologiczne. Sekcja Socjologii Miasta, Warszawa, s. 189-199.

Iwona Żuraszek-Ryś

\section{The decommunization of Zielona Góra's urbanonyms}

The article describes the process of decommunization of urbanonyms in one of the Polish voivodeship capitals, Zielona Góra. It presents both the changes in naming we are witnessing currently and past ones. During the first removal of communist patrons we still had to deal with the period of the Polish People's Republic after Stalin's death and Władysław Gomułka’s coming to power. However, the changes introduced at that time were quite limited and concerned a small number of people who were no longer in power - Stalin and Marshal Rola-Żymierski. The proper decommunization was related to the political transformation after 1989. The previous urbanonyms, based mainly on anthroponyms, were replaced with names referring to people and events that could not be commemorated before and were to be erased from history (e.g. ul. Hanki Sawickiej changed to $u l$. gen. Okulickiego). In addition, the changes were motivated by the need 
to commemorate local activists and heroes, and to highlight the history and topography of the city. The last decommunization was enforced by the enactment of the Act on the Prohibition of Propagation of Communism or Other Totalitarian Regimes and ended quite recently (the last street name change was voted on on March 27, 2018). Four streets in Zielona Góra have been renamed, including two referring to military organizations associated with the communist movement (ul. Armii Ludowej $\rightarrow$ ul. Władystawa Jagietly and ul. II Armii $\rightarrow$ ul. Żotnierzy 2 Armii), and two based on dates (ul. Przylep-22 Lipca $\rightarrow$ ul. Przylep-Solidarności and ul. Przylep-9 Maja $\rightarrow$ ul. Przylep-8 Maja).

Therefore, in the case of both decommunizations, ideological considerations prevailed, and to a lesser degree so did economic or cultural ones.

KEYWORDS: urbanonym, decommunization, motivations for changing the names of streets and squares.

dr Iwona Żuraszek-Ryś - Instytut Filologii Polskiej, Uniwersytet Zielonogórski; zainteresowania naukowe: onomastyka (zwłaszcza toponimia oraz nazewnictwo miejskie Zielonej Góry i okolicy), historia języka polskiego. 